\title{
Definition of bases in 23S rRNA essential for ribosomal subunit association
}

\author{
ÜLO MAIVÄLI and JAANUS REMME
}

Department of Molecular Biology, Tartu University, Tartu, Estonia

\begin{abstract}
The ribosome is a two-subunit molecular machine, sporting a working cycle that involves coordinated movements of the subunits. Recent structural studies of the $70 S$ ribosome describe a rather large number of intersubunit contacts, some of which are dynamic during translocation. We set out to determine which intersubunit contacts are functionally indispensable for the association of ribosome subunits by using a modification interference approach. Modification of the N-1 position of A715, A1912, or A1918 in Escherichia coli 50S subunits is strongly detrimental to $70 \mathrm{~S}$ ribosome formation. This result points to $23 \mathrm{~S}$ rRNA helices 34 and 69, and thus bridges B2a and B4, as essential for ensuring stability of the 70S ribosome.
\end{abstract}

Keywords: ribosome; $23 S$ rRNA; intersubunit bridges; modification interference

\section{INTRODUCTION}

All ribosomes consist of two unequal subunits. Although the large subunit catalyses the peptidyl transferase reaction and the small subunit catalyses decoding of mRNA codons, the two-subunit organization itself is a prerequisite for dynamic ribosome functioning, for example, translocation (Spirin 2002). The ribosome stays together by virtue of tRNAs that interconnect the subunits and a number of intersubunit bridges. Nevertheless, tRNAs are not needed for subunit association per se (e.g., Blaha et al. 2002).

The presence of various rRNA regions in intersubunit contacts was determined by the use of footprinting (Chapman and Noller 1977; Herr and Noller 1979) and modification interference technologies (Herr et al. 1979). The first unambiguously located intersubunit contact was placed by chemical cross-linking between $23 \mathrm{~S}$ rRNA helix 69 and $16 \mathrm{~S}$ rRNA helices 44 and 45 (Mitchell et al. 1992). More recent footprinting studies determined a number of rRNA positions that participate in intersubunit contacts (Merryman et al. 1999a,b). Recent medium-resolution X-ray crystallography (Yusupov et al. 2001) and cryo-EM-based models of the 70 S ribosome (Gabashvili et al. 2000; Gao et al. 2003) define, in addition to RNA-RNA bridges, several proteinprotein and protein-RNA intersubunit bridges. Generally,

Reprint requests to: Jaanus Remme, Department of Molecular Biology, Tartu University, Riia 23, 51010 Tartu, Estonia; e-mail: jremme@ebc.ee; fax: +372 7420286 .

Article and publication are at http://www.rnajournal.org/cgi/doi/ 10.1261/rna.5220504. intersubunit bridges as defined by structural studies are in good agreement with data obtained by chemical methods. The Yusupov et al. (2001) model incorporates 12 bridges, which translate into more than 30 individual interactions between $50 \mathrm{~S}$ and $30 \mathrm{~S}$ subunits. These bridges seem to be largely conserved between the three kingdoms of life (Spahn et al. 2001; Gao et al. 2003). Notably, the more central positions (as defined by proximity to peptidyl transferase $[\mathrm{PT}]$ and decoding centers) in both $30 \mathrm{~S}$ and $50 \mathrm{~S}$ are occupied by bridges, consisting entirely of RNA (bridges B2a, $\mathrm{B} 2 \mathrm{~b}, \mathrm{~B} 2 \mathrm{c}, \mathrm{B} 3$, and $\mathrm{B} 7 \mathrm{a}$ ), whereas protein-protein and protein-RNA bridges (B1a, B1b, B7b, and B8, plus elements of B4, B5, and B6) are more peripheral (Yusupov et al. 2001; Gao et al. 2003). Centrally located RNA-RNA bridges contribute more than $80 \%$ of the intersubunit contacts (Gao et al. 2003). Recently, it has been shown that central RNARNA bridges are static during EF-G-GTP binding whereas some peripheral protein-containing bridges change conformation, resulting in a major ratchetlike movement of ribosomal subunits (Gao et al. 2003; Valle et al. 2003). This implies that the core interactions between ribosomal subunits in the 70S ribosome might consist of the centrally located RNA-RNA bridges as opposed to a more regulatory role for the peripheral bridges.

We have used chemical modification of $23 \mathrm{~S}$ rRNA inside the 50S subunits in combination with selection of functional $50 \mathrm{~S}$ to determine the nucleotides in $23 \mathrm{~S}$ rRNA that are functionally important for the stability of the 70S ribosome. We found that dimethyl sulfate (DMS) modifications of $\mathrm{N}-1$ positions of adenines 715 in helix 34 and 1912 as well 
as 1918 in helix 69 interfere with 70S ribosome formation. These results point to two intersubunit bridges, B2a and B4, as essential for the stability of ribosomal subunit interaction.

\section{RESULTS AND DISCUSSION}

Our intention was to chemically modify $50 \mathrm{~S}$ ribosomal subunits at a low level, so that the majority of the 50S population would retain its ability to bind $30 \mathrm{~S}$ subunits. After modification with DMS or 1-cyclohexyl-3-(2-morpholinoethyl)carbodiimide metho- $p$-toluene sulfonate (CMCT), $50 \mathrm{~S}$ subunits were reassociated with unmodified $30 \mathrm{~S}$ subunits to determine which modified positions are excluded from the $70 \mathrm{~S}$ ribosomes. Ribosomal subunit reassociating and subsequent sucrose gradient centrifugation was carried out in $6 \mathrm{mM} \mathrm{MgCl}_{2}$ to obtain partial 70S formation. Under these conditions, native subunits reassociate with $50 \%-60 \%$ efficiency (Fig. 1A). All reassociation experiments that were performed in $6 \mathrm{mM} \mathrm{MgCl}$ exhibited ribosome sedimentation rates of $\sim 60 \mathrm{~S}$ (Fig. $1 \mathrm{~A}-\mathrm{D}$ ), in accordance with Blaha et al. (2002). To avoid overmodification, we used two concentrations of DMS, $17 \mathrm{mM}$ and $85 \mathrm{mM}$. This corresponds to DMS/50S molar ratios of $8.5 \times 10^{3}$ and $4.25 \times 10^{4} .50 \mathrm{~S}$ subunits, modified with the lower concentration of DMS or with $\mathrm{CMCT}$, reassociated with $30 \%-40 \%$ efficiency in 6 $\mathrm{mM} \mathrm{MgCl}$ and sedimented with velocities similar to unmodified ribosomes (Fig. 1B,C). Therefore, modification of 50 S subunits with CMCT or with $17 \mathrm{mM}$ DMS reduces its reassociation efficiency by $20 \%-50 \%$. Such an intermediate level of counterselection makes it likely that (1) a specific interference pattern can be found and (2) positions that are counterselected in our assay are indeed relevant as major contributors to $70 \mathrm{~S}$ stability. 50S subunits that were modified with $85 \mathrm{mM}$ DMS and reassociated in $6 \mathrm{mM} \mathrm{MgCl}_{2}$ produced two partially overlapping peaks in the $70 \mathrm{~S}$ region (Fig. 1D). Therefore, we also reassociated these 50S subunits in $13 \mathrm{mM} \mathrm{MgCl}_{2}$, where 70S ribosomes sedimented as one peak (Fig. 1E). We could not perform the selection experiment by including tRNA because under stable tRNA binding conditions, for example, $13 \mathrm{mM} \mathrm{MgCl}_{2}$ (Schilling-Bartetzko et al. 1992), all modified 50S reassociates into $70 \mathrm{~S}$ ribosome (data not shown). Hence no selection was possible.

Scanning of the domains II-V of $23 \mathrm{~S}$ rRNA by reverse transcriptase-directed primer extension revealed that modifications at two regions were strongly counterselected in reassociated $70 S$ subunits.

First, modification of A1912 and A1918 at their N-1 positions by DMS strongly interfered with $70 \mathrm{~S}$ ribosome formation (Fig. 2). The interference was more pronounced if $70 \mathrm{~S}$ ribosomes were formed in $6 \mathrm{mM} \mathrm{MgCl}_{2}$ (Fig. 2, lanes 3-6). When $13 \mathrm{mM} \mathrm{MgCl}$, was used for $70 \mathrm{~S}$ reassociation, somewhat less interference was observed (Fig. 2, lanes 7,8). A1912 and A1918 are a part of the loop of 23S rRNA helix 69 , contributing to the intersubunit bridge B2a.

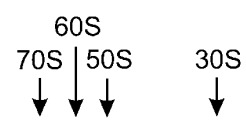

A

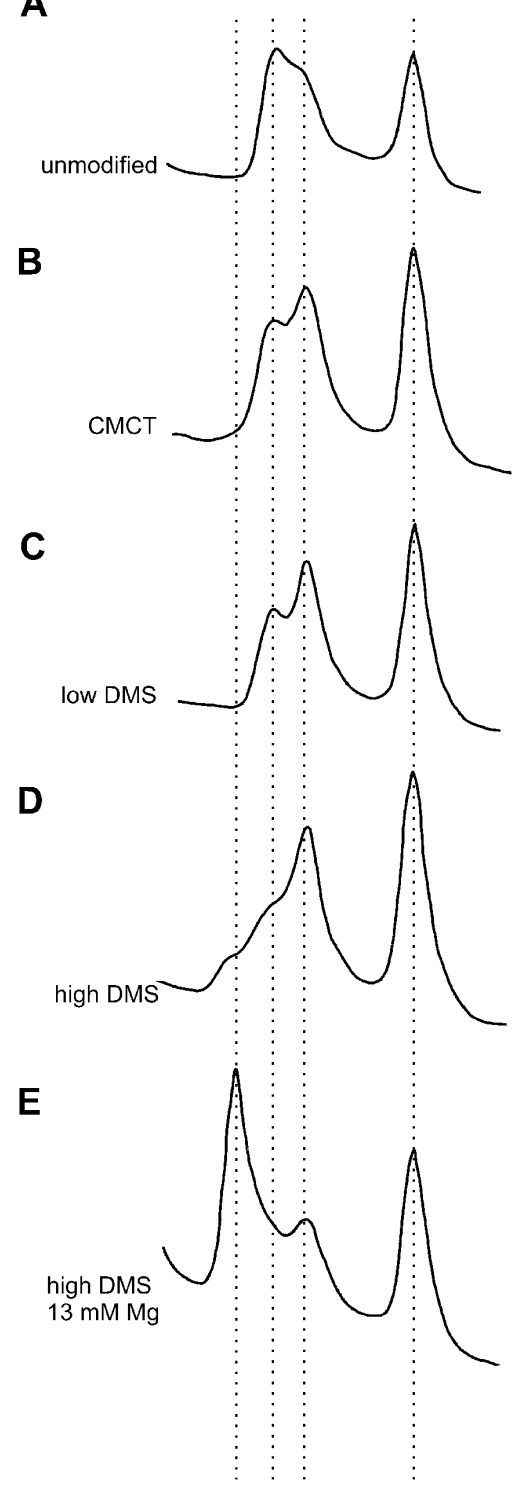

FIGURE 1. Sucrose gradient patterns of modified and subsequently reassociated $50 \mathrm{~S}$ subunits. Ribosomal particles were separated by sucrose gradient centrifugation. $(A)$ unmodified $50 \mathrm{~S}$ reassociated in $6 \mathrm{mM} \mathrm{MgCl}_{2}$. (B) 50S, modified with CMCT were reassociated in $6 \mathrm{mM} \mathrm{MgCl}_{2}$. (C) 50S, modified with $17 \mathrm{mM}$ of DMS, were reassociated in $6 \mathrm{mM} \mathrm{MgCl}_{2}$. (D) 50S, modified with $85 \mathrm{mM}$ DMS, were reassociated in $6 \mathrm{mM} \mathrm{MgCl}_{2}$. (E) 50S, modified with $85 \mathrm{mM}$ DMS, were reassociated in $13 \mathrm{mM} \mathrm{MgCl}_{2}$.

Second, DMS modification of A715 conferred strong interference to $70 \mathrm{~S}$ reassociation at $6 \mathrm{mM} \mathrm{MgCl}_{2}$, but did not interfere at $13 \mathrm{mM} \mathrm{MgCl}_{2}$ (Fig. 3). A715 is a part of the loop of helix 34 and intersubunit bridge B4.

No CMCT-specific interferences were found in $23 \mathrm{~S}$ rRNA, although a number of CMCT-modified uridines were detected. The number of positions accessible to DMS 


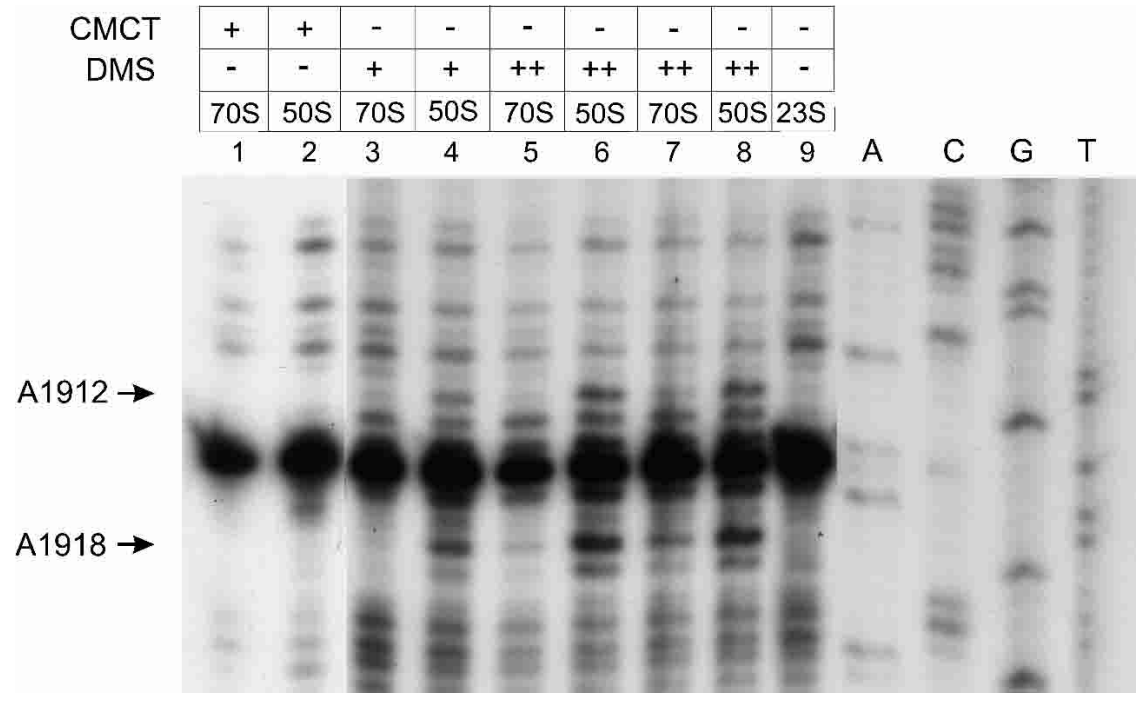

FIGURE 2. Reverse transcriptase analysis of the positions of the DMS and CMCT modifications in the 23S rRNA. Positions A1912 and A1918, whose modification interfere with 50S reassociation, are denoted by arrows. The dideoxy sequencing lanes are indicated by A, C, G, and T. (+) 17 mM DMS; (++) $85 \mathrm{mM}$ DMS. (Lanes 1-6) selection experiments done in $6 \mathrm{mM}$ $\mathrm{MgCl}_{2}$; (lanes 7,8) selection experiments done in $13 \mathrm{mM} \mathrm{MgCl}$.

and CMCT modification in 50S subunits was similar to the results summarized in Egjeberg et al. (1990).

We have determined three positions in 23S rRNA that are functionally indispensable for $70 \mathrm{~S}$ ribosome formation. The interfering positions, being a subset of modifiable positions at or near intersubunit contact areas, are located at two known intersubunit bridges, B2a and B4. This implicates bridges $\mathrm{B} 2 \mathrm{a}$ and $\mathrm{B} 4$ as having a central role in the stability of $70 \mathrm{~S}$ ribosomes (rather than a dynamic or regulatory role). This is in accordance with their recent assignment as immobile in the large-scale intersubunit rearrangement that accompanies ribosomal translocation (Gao et al. 2003; Valle et al. 2003). Although bridge B2a is one of the central RNAonly bridges (Yusupov et al. 2001), bridge B4 is more peripheral and, in addition to RNA (helix 34 of $23 \mathrm{~S}$ rRNA and helix 20 of $16 \mathrm{~S}$ rRNA), has a protein component in the $30 \mathrm{~S}$ side (positions 59-63 and 86-87 of S15; Culver et al. 1999; Gao et al. 2003). However, what they have in common is that interfering positions at both helices 69 and 34 protrude from the main body of $50 \mathrm{~S}$ subunit (Fig. 4).

In the medium-resolution X-ray crystallography-based model of Thermus thermophilus $70 \mathrm{~S}$ ribosome, nucleotides A1913, C1914, and A1918 are in contact with the 16S rRNA helix 44 (Yusupov et al. 2001) whereas cryo-EM studies of Escherichia coli 70S ribosome point to A1912 and A1913 as the $50 \mathrm{~S}$ component of $\mathrm{B} 2 \mathrm{a}$ (Gao et al. 2003). We have found that N-1 modifications of A1912 and A1918 cause disruption of intersubunit association whereas modification of A1913 does not (Fig. 2). N-1 positions of adenine have been shown to be involved in minor groove RNA interactions (Nissen et al. 2001). Indeed, bridge B2a, which is made of the loop of helix 69 (23S rRNA positions 1912-1918) on the $50 \mathrm{~S}$ side, has been found to dock into helix 44 of $16 \mathrm{~S}$ rRNA by minor groove-minor groove interactions ( $\mathrm{Yu}-$ supov et al. 2001). Therefore, we have good reason to believe that observed interferences with $70 \mathrm{~S}$ ribosome formation are caused by disruption of specific interactions of A1912 and A1918 with 16S rRNA helix 44. Accordingly, N-1 positions of A1912 and A1918 are likely to be involved in B2a formation via minor groove interaction with helix 44 of $16 \mathrm{~S}$ rRNA.

Interestingly, helix 69 contains three pseudouridines ( $\Psi 1911, \mathrm{~m} \Psi 1915$, and

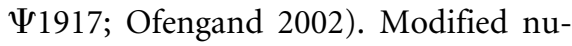
cleosides are often found in functionally important regions of rRNA (Ofengand 2002). The fact that $\Psi 1915$ and $\Psi 1917$ are well conserved in all three kingdoms stresses the importance of the helix-loop 69 in ribosome functioning. Indeed, helix 69 contacts tRNAs at both the A site and the P site (Yusupov et al. 2001; Stark et al. 2002; Bashan et al. 2003). This makes it both a central structural component of the $70 \mathrm{~S}$ ribosome and a good candidate for a mediator

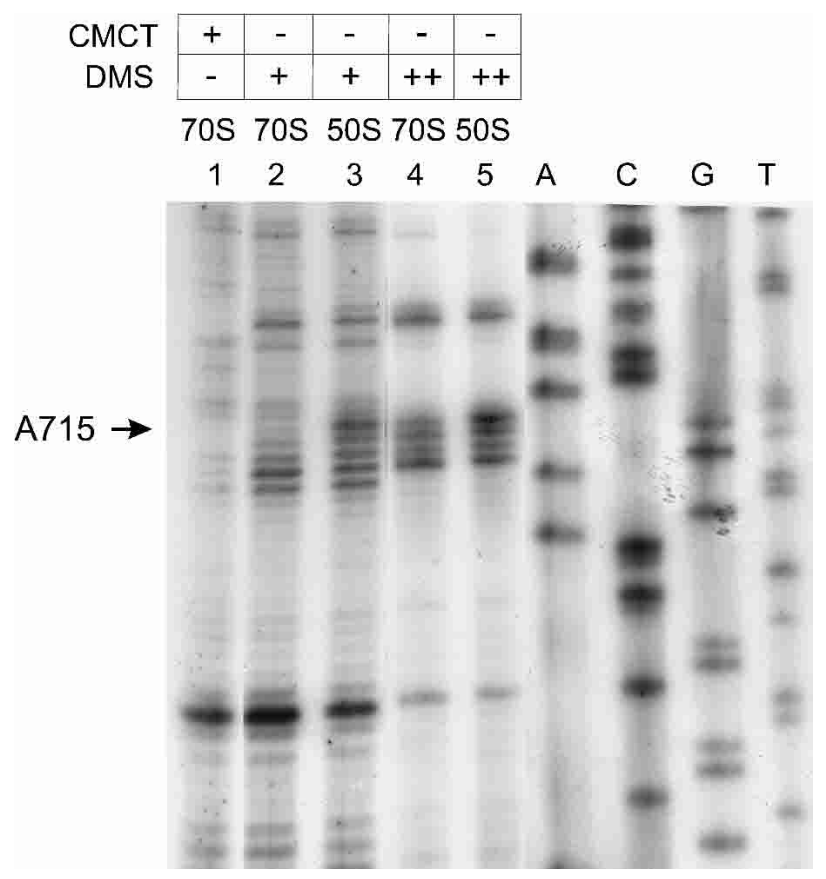

FIGURE 3. Reverse transcriptase analysis of the positions of the DMS and CMCT modifications in the 23S rRNA. Position A715, whose modification interferes with $50 \mathrm{~S}$ reassociation, is denoted by an arrow. The dideoxy sequencing lanes are indicated by A, C, G, and T. (+) 17 mM DMS; (++) $85 \mathrm{mM}$ DMS. (Lanes 1-3) selection experiments done in $6 \mathrm{mM} \mathrm{MgCl}_{2}$; (lanes 4,5) selection experiments done in $13 \mathrm{mM} \mathrm{MgCl}_{2}$. 


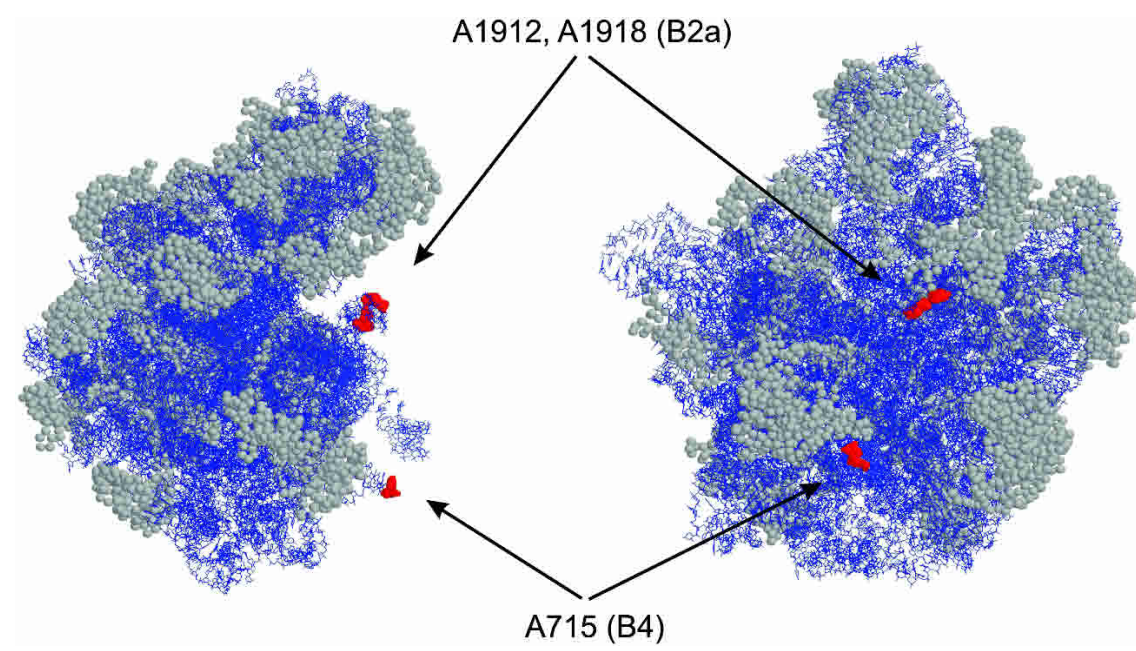

FIGURE 4. Modeling of interfering positions into the crystal structure of Deinococcus radiodurans 50S subunits (Harms et al. 2001; PDB accession code 1KC9). The left view is from the $\mathrm{L} 1$ side and the right view is from the $30 \mathrm{~S}$ side of the $50 \mathrm{~S}$ subunit. Arrows indicate interfering positions (E. coli numbering) and corresponding bridges. RasWin molecular graphics was used to highlight interfering positions in red spacefill. The rest of the RNA is blue and $\alpha$-carbons of r-proteins are in gray spacefill.

of signals between $50 \mathrm{~S}$ and $30 \mathrm{~S}$ subunits during the elongation cycle. Mutations in the helix 69 have been found to affect translational fidelity (O'Connor and Dahlberg 1995), supporting its role in coordinating crosstalk between two ribosomal subunits. Also noteworthy is the observation, based on hydroxyl-radical footprinting, that the ribosome anti-association factor IF3 and 23S rRNA helix 69 appears to contact overlapping areas in the $30 \mathrm{~S}$ subunit (Dallas and Noller 2001). This suggests that disrupting bridge 2a may also be the way to ribosomal subunit dissociation in situ. Conformational flexibility of helix 69 (Ban et al. 2000; Harms et al. 2001; Yusupov et al. 2001) might enable it to carry the A site peptidyl-tRNA acceptor stem during translocation, making it effectively a molecular crane (Bashan et al. 2003). Nevertheless, our results clearly show that helix 69 can productively participate in intersubunit contacts in the absence of tRNAs. Thus, the essentially static structural role of helix 69 in ensuring the stability of the 70S ribosome and the aforementioned more dynamic tRNA-dependent roles appear to be separable.

\section{MATERIALS AND METHODS}

$50 \mathrm{~S}$ subunits were dissociated from tight-coupled 70S ribosomes by sucrose gradient centrifugation in $1 \mathrm{mM} \mathrm{MgCl}_{2}$ (Bommer et al. 1996). Modification of $50 \mathrm{~S}$ subunits was conducted as in Stern et al. (1988). Eight $\mathrm{A}_{260}$ units of $50 \mathrm{~S}$ and $1.2 \mu \mathrm{L}$ or $6 \mu \mathrm{L}$ of DMS stock ( $4 \mu \mathrm{L}$ DMS, $16 \mu \mathrm{L}$ ethanol) were used per $150 \mu \mathrm{L}$ DMS reaction (17 mM and $85 \mathrm{mM}$ DMS, respectively) and $75 \mu \mathrm{L}$ of CMCT stock $(126 \mathrm{mg} / \mathrm{mL})$ per $150 \mu \mathrm{L}$ CMCT reaction $(149 \mathrm{mM}$ CMCT). Modification reactions commenced for $5 \mathrm{~min}$ at $37^{\circ} \mathrm{C}$ and were stopped by addition of $15 \mu \mathrm{L} 0.1 \%$ adenine on an ice bath. Stern et al. (1988) state that under conditions similar to our 11: $91-102$. low DMS (17 mM) or CMCT modification protocols, no more than a few modifications per $23 \mathrm{~S}$ rRNA molecule occur. Ribosomes were further purified from modifying agents by Sephacryl S400 spin columns (Amersham Pharmacia), equilibrated in buffer M6 (6 $\mathrm{mM} \mathrm{MgCl} 2,60 \mathrm{mM} \mathrm{NH}_{4} \mathrm{Cl}, 30 \mathrm{mM}$ Tris$\mathrm{HCl}$ at $\mathrm{pH} 7.5,60 \mathrm{mM} \mathrm{KCl}, 5 \mathrm{mM}$ 2-mercapto ethanol) or M13 (same as M6, except with $13 \mathrm{mM} \mathrm{MgCl}_{2}$; Maiväli et al. 2002). $70 \mathrm{~S}$ ribosomes were reassociated in buffer M6 or M13 by adding $8 \mathrm{~A}_{260}$ units of unmodified $30 \mathrm{~S}$ subunits to modified $50 \mathrm{~S}$ subunits in $1 \mathrm{~mL}$ final volume. Reassociation was carried out for $30 \mathrm{~min}$ at $37^{\circ} \mathrm{C}$. $70 \mathrm{~S}$ ribosomes and $50 \mathrm{~S}$ subunits were fractionated by $10 \%-$ $20 \%$ sucrose gradient centrifugation in M6 or M13 (Beckmann rotor SW 28, 20.4k rpm, $17 \mathrm{~h}$ ) and rRNA was purified by silica binding as in Maiväli et al. (2002). Primer extension was done as in Stern et al. (1988). 23S rRNA domains II-V were scanned for modifications. Domains I and VI are not suspect as intersubunit contact areas (Yusupov et al. 2001). The identity of interfering positions was ascertained by at least five independent replications of the modification-selection experiment. Band densitometric analysis and quantification of observed interferences at $6 \mathrm{mM} \mathrm{MgCl}_{2}$ revealed a $70 \%-90 \%$ reduction of band intensities in reassociated $70 \mathrm{~S}$ ribosomes if compared with the $50 \mathrm{~S}$ fractions (data not shown).

\section{ACKNOWLEDGMENTS}

We thank Dr. Tanel Tenson and M.Sc. Silja Kuusk (both University of Tartu, Estonia) for helpful comments on the manuscript. The research was supported by Estonian Science Foundation Grant 4425, EU framework V Grant No. QLK2-CT-2000-00935, and HHMI International Research Grant No. 55000332.

The publication costs of this article were defrayed in part by payment of page charges. This article must therefore be hereby marked "advertisement" in accordance with 18 USC section 1734 solely to indicate this fact.

Received October 31, 2003; accepted January 9, 2004.

\section{REFERENCES}

Ban, N., Nissen, P., Hansen, J., Moore, P.B., and Steitz, T.A. 2000. The complete atomic structure of the large ribosomal subunit at $2.4 \AA$ resolution. Science 289: 905-920.

Bashan, A., Agmon, I, Zarivach, R., Schluenzen, F., Harms, J., Berisio, R., Bartels, H., Franceschi, F., Auerbach, T., Hansen, H.A., et al. 2003. Structural basis of the ribosomal machinery for peptide bond formation, translocation, and nascent chain progression. Mol. Cell

Blaha, G., Burkhardt, N., and Nierhaus, K.H. 2002. Formation of 70 S ribosomes: Large activation energy is required for the adaptation of exclusively the small ribosomal subunit. Biophys. Chem. 96: 153161. 
Bommer, U., Burkhardt, N., Jünemann, R., Spahn, C.M.T., TrianaAlonso, F.J., and Nierhaus, K.H. 1996. Ribosomes and polysomes. In Subcellular fractionation. A practical approach (eds. J. Graham and D. Rickwoods), pp. 271-301. Oxford University Press, Oxford, UK.

Chapman, N.M. and Noller, H.F. 1977. Protection of specific sites in $16 \mathrm{~S}$ RNA from chemical modification by association of $30 \mathrm{~S}$ and 50 S ribosomes. J. Mol. Biol. 109: 131-149.

Culver, G.M., Cate, J.H., Yusupova, G.Z., Yusupov, M.M., and Noller, H.F. 1999. Identification of an RNA-protein bridge spanning the ribosomal subunit interface. Science 285: 2133-2136.

Dallas, A. and Noller, H.F. 2001. Interaction of translation initiation factor 3 with the 30 S ribosomal subunit. Mol. Cell 8: 855-864.

Egjeberg, J., Larsen, N., and Garrett, R.A. 1990. Structural map of $23 \mathrm{~S}$ rRNA. In The ribosome: Structure, function and evolution (eds. W.E. Hill et al.), pp. 168-179. American Society for Microbiology, Washington, DC.

Gabashvili, I.S., Agrawal, R.K., Spahn, C.M., Grassucci, R.A., Svergun, D.I., Frank, J., and Penczek, P. 2000. Solution structure of the E. coli $70 S$ ribosome at $11.5 \AA$ resolution. Cell 100: 537-549.

Gao, H., Sengupta, J., Valle, M., Korostelev, A., Eswar, N., Stagg, S., Roey, P., Agrawal, R.K., Harvey, S.C., Sali, A., et al. 2003. Study of the structural dynamics of the E. coli $70 S$ ribosome using real-space refinement. Cell 113: 789-801.

Harms, J., Schluenzen, F., Zarivach, R., Bashan, A., Gat, S., Agmon, I., Bartels, H., Franceschi, F., and Yonath, A. 2001. High resolution structure of the large ribosomal subunit from a mesophilic eubacterium. Cell 107: 679-688.

Herr, W. and Noller, H.F. 1979. Protection of specific sites in $23 \mathrm{~S}$ and $5 \mathrm{~S}$ RNA from chemical modification by association of $30 \mathrm{~S}$ and 50 S ribosomes. J. Mol. Biol. 130: 421-432.

Herr, W., Chapman, N.M., and Noller, H.F. 1979. Mechanism of ribosomal subunit association: Discrimination of specific sites in 16 S RNA essential for association activity. J. Mol. Biol. 130: 433449.

Maiväli, Ü., Pulk, A., Loogväli, E., and Remme, J. 2002. Accessibility of phosphates in domain I of $23 \mathrm{~S}$ rRNA in the ribosomal $50 \mathrm{~S}$ subunit as detected by $\mathrm{R}_{\mathrm{P}}$ phosphorothioates. Biochim. Biophys. Acta 1579: 1-7.
Merryman, C., Moazed, D., Daubresse, G., and Noller, H.F. 1999a. Nucleotides in 23S rRNA protected by the association of $30 \mathrm{~S}$ and 50S ribosomal subunits. J. Mol. Biol. 285: 107-113.

Merryman, C., Moazed, D., McWhirter, J., and Noller, H.F. 1999b. Nucleotides in 16S rRNA protected by the association of $30 \mathrm{~S}$ and 50S ribosomal subunits. J. Mol. Biol. 285: 97-105.

Mitchell, P., Osswald, M., and Brimacombe, R. 1992. Identification of intermolecular RNA cross-links at the subunit interface of the Escherichia coli ribosome. Biochemistry 31: 3004-3011.

Nissen, P., Ippolito, J.A., Ban, N., Moore, P.B., and Steitz, T.A. 2001. RNA tertiary interactions in the large ribosomal subunit: The Aminor motif. Proc. Natl. Acad. Sci. 98: 4899-4903.

O'Connor, M. and Dahlberg, A.E. 1995. The involvement of two distinct regions of $23 \mathrm{~S}$ ribosomal RNA in tRNA selection. J. Mol. Biol. 254: $838-847$.

Ofengand, J. 2002. Ribosomal RNA pseudouridines and pseudouridine synthases. FEBS Lett. 514: 17-25.

Schilling-Bartetzko, S., Bartetzko, A., and Nierhaus, K.H. 1992. Kinetic and thermodynamic parameters for tRNA binding to the ribosome and for the translocation reaction. J. Biol. Chem. 267: 4703-4712.

Spahn, C.M.T., Beckmann, R., Eswar, N., Penczek, P.A., Sali, A., Blobel, G., and Frank, J. 2001. Structure of the 80 S ribosome from Saccharomyces cerevisiae-tRNA-ribosome and subunit-subunit interactions. Cell 107: 373-386.

Spirin, A.S. 2002. Ribosome as a molecular machine. FEBS Lett. 514: $2-10$.

Stark, H., Rodnina, M.V., Wieden, H.J., Zemlin, F., Wintermeyer, W., and van Heel, M. 2002. Ribosome interactions of aminoacyl-tRNA and elongation factor Tu in the codon-recognition complex. Nat. Struct. Biol. 9: 849-854.

Stern, S., Moazed, D., and Noller, H.F. 1988. Structural analysis of RNA using chemical and enzymatic probing monitored by primer extension. Methods Enzymol. 164: 481-489.

Valle, M., Zavialov, A., Sengupta, J., Rawat, U., Ehrenberg, M., and Frank, J. 2003. Locking and unlocking ribosomal motions. Cell 114: $123-134$

Yusupov, M.M., Yusupova, G.Z., Baucom, A., Lieberman, K., Earnest, T.N., Cate, J.H., and Noller, H.F. 2001. Crystal structure of the ribosome at $5.5 \AA$ resolution. Science 292: 883-896. 


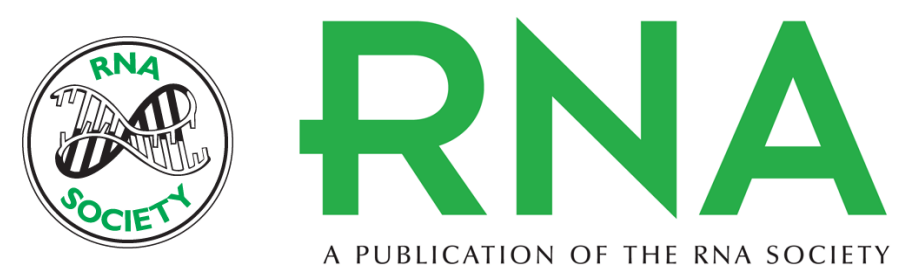

\section{Definition of bases in 23S rRNA essential for ribosomal subunit association}

ÜLO MAIVÄLI and JAANUS REMME

RNA 2004 10: 600-604

References This article cites 25 articles, 5 of which can be accessed free at:

http://rnajournal.cshlp.org/content/10/4/600.full.html\#ref-list-1

\section{License}

Email Alerting Receive free email alerts when new articles cite this article - sign up in the box at the Service top right corner of the article or click here. 